\title{
Openness and Deindustrialization: A Turkish Case
}

\author{
Halit Yanikkaya* \\ Gebze Technical University
}

\author{
Abdullah Altun** \\ TÜBITAK
}

\author{
Pinar Tat ${ }^{* * *}$ \\ Gebze Technical University
}

\begin{abstract}
Since the 1980s, a decreasing trend in employment and real value added shares in the manufacturing sector in some developing countries including Turkey is considered a sign of premature deindustrialization (Rodrik, 2016). We examine this argument and the effects of trade shares and policies on the industrialization process by utilizing different openness measures for the periods 1995-2009 and 2005-2014 for more than twenty manufacturing and service sectors. The estimations show that the value added shares of net exporter manufacturing sectors increase significantly and the employment shares decrease significantly, which may suggest employment deindustrialization in Turkey. However, this negative effect is not valid for all manufacturing sectors. Hence, we conclude that Turkey has not been on the deindustrialization track during the period considered. Estimates for the relationship between openness and deindustrialization suggest that trade, FDI inflows, and backward participation have negative impacts on the share of employment and value added of manufacturing sectors. Overall, Turkey should design and pursue proactive trade and financial policies to effectively integrate with the global economy and benefit from it.
\end{abstract}

Key words: Trade openness; de/industrialization; sectoral employment; sectoral output; Turkey JEL Classification: F14; O14; O24

\section{Açıklık ve Sanayisizleșme: Türkiye Örneği}

\begin{abstract}
Özet
1980'lerden bu yana, Türkiye dahil olmak üzere bazı gelişmekte olan ülkelerde imalat sanayinde istihdam ve reel katma değer paylarındaki düşüş eğilimi, erken sanayisizleşmenin bir işareti olarak görülmektedir (Rodrik, 2016). Bu argümanı ve ticaret payları ve politikalarının sanayileşme sürecine etkilerini farklı açıklık değişkenleri kullanarak 1995-2009 ve 2005-2014 dönemleri için yirmiden fazla sanayi ve hizmet sektörü için incelemekteyiz. Sonuçlar, net ihracatçı imalat sanayi sektörlerinin katma değer paylarının önemli ölçüde arttığını ve istihdam paylarının ise önemli ölçüde azaldığını göstermektedir. Bu durum zayıf da olsa Türkiye'de istihdam sanayisizleşmesine işaret etmektedir. Ancak, bu olumsuz etki tüm sanayi sektörleri için geçerli değildir. Dolayısıyla, Türkiye'nin, incelenen dönemde sanayisizleşme yolunda olmadığı sonucuna varmaktayız. Açıklık ve sanayisizleşme ilişkisini inceleyen tahminler; ticaret, DYY girişleri ve geriye dönük katılımın, sanayi sektörlerinin istihdam payı ve katma değeri üzerinde olumsuz etkileri olduğunu göstermektedir. Genel olarak, Türkiye küresel ekonomiyle etkin bir şekilde bütünleşmek ve bundan faydalanmak için proaktif ticaret ve finansal politikalar tasarlamalı ve izlemelidir.
\end{abstract}

Anahtar Kelimeler: Ticaret açıklığı; sanayi(siz)leşme; sektörel istihdam; sektörel çıktı; Türkiye JEL Sinıflandırmasi: F14; O14; O24

\footnotetext{
*Prof.Dr. Halit Yanikkaya, Department of Economics, Gebze Technical University (halityanikkaya @ gtu.edu.tr). ** Dr. Abdullah Altun, TUBITAK (abdullah.altun@tubitak.gov.tr)

***Ar. Gör. Pınar Tat, Department of Economics, Gebze Technical University (pinartat@gtu.edu.tr), Contact person.
} 


\section{Introduction}

Productivity differences among the main sectors of an economy are the key drivers of economic growth for developing countries. One channel is the reallocation of labor across sectors from less productive ones to higher productive sectors such as from agriculture to manufacturing, also known as structural transformation. In developing countries, the manufacturing sector is still seen as the engine of economic growth thanks to its dynamic increasing returns to scale and ability to produce tradeables. On the other hand, the service sector is generally regarded as a less productive one because human capital, technology, and knowledge are not sufficient to create productive service sectors including software and finance. In some cases, the reallocation goes in the opposite direction, from higher productive sectors to less productive ones. This process hinders the productivity and growth potential of an economy, which is called premature deindustrialization by McMillan and Rodrik (2011). Prematurely deindustrialized countries are more likely to have a steady and lower level of manufacturing employment and value added as a share of gross domestic product (GDP) compared to previously industrialized countries. Indeed, this phenomenon can also be defined as a jobless growth of manufacturing in the formal sector and faster growth of services than the overall manufacturing sector.

There are many possible explanations for this situation. The first one is the decrease in demand for manufacturing goods, which leads to both employment and output deindustrialization. The second one is the enhancement of technology and knowledge, which generates more labor saving production processes and replaces workers with automatic functioning machines. This scenario is generally valid for developed countries and creates just employment deindustrialization, not output deindustrialization. In fact, this mechanism works through the declining price of manufacturing goods. However, since developing countries are mostly price takers in the world markets, this explanation may not be valid for them. Therefore, trade openness can be a new explanation for the deindustrialization process in developing countries. These economies lose their comparative advantages in manufacturing products in international areas. They cannot differentiate their products and close the gap between new and traditional economic sectors. As a result, domestic production declines and this process displaces workers from manufacturing and agriculture sectors to service sectors. In addition, the lower manufacturing prices in developed countries, because of technological progress, may be transmitted to developing countries via trade activities (Dincer and Tekin-Koru, 2019). Therefore, they eventually take earlier steps into service sectors before reaching the sufficient level of manufacturing output and experiences of industrialization. In fact, Boratav (2016) 
claims that an emergence of deindustrialization in Turkey started in 1995 with the Customs Union Agreement with the European Union.

Some studies argue that trade liberalization leads to higher productivity via utilizing excess labor in the manufacturing market (Ferreira and Rossi, 2003; Fernandes, 2003). Dehejia and Panagariya (2014) find that increases in the share of the service sector in India is inevitable as consequences of the emerging manufacturing sector. Ahsan and Mitra (2014) analyze the effect of tariffs and regulatory variation across states on employment shares in India. Their results suggest that trade liberalization leads to an increase in labor's share for small and laborintensive firms but a reduction for larger and less labor-intensive firms. In contrast, MenezesFilho and Muendler (2011) provide evidence of the transition of workers from manufacturing sectors to services and unemployment in Brazil. Similarly, Jenkins (2015) indicates that the manufacturing sector in Brazil has a declining trend because of Chinese competition and changes in the country's trade balance in manufactures. Rasiah (2011) suggests that the reason for a decrease in manufacturing value added share of GDP in Malaysia is the lower productivity level of electric-electronics, textiles, and transport equipment. Bogliaccini (2013) shows that integration to the global economy fastens a deindustrialization process in Latin America, which decreases formal employment and increases inequality. Similarly, Castillo and Martins (2016) assert that the share of manufacturing employment in Latin American countries has decreased because of primary goods and resource-based activities in trade. These countries are specialized in low productive services. Rodrik (2016) claims that since the 1980s, there exists a decreasing trend in employment and real value added shares of the manufacturing sector in some developing countries such as Turkey. Banga (2016) finds the displacing effect of backward and forward linkages on the Indian domestic labor market. López (2017) provides evidence of reduction in the manufacturing industry owing to a fall in effective tariff in Colombia.

However, Firpo and Pieri (2013) find no effect of trade openness on labor reallocation for Brazil. Turco and Maggioni (2013) support the internationalization and employment creative effects of trade on Turkish plants. Bamber and Gereffi (2013) claim the positive association between GVC participation and employment growth exists thanks to an expansion of production, which acquires cheaper inputs from international markets through an increase in demand. Moreover, Meçik and Aytun (2018) analyze the deindustrialization process in Turkey for the period 2003-2011 considering the regions and technology levels of industries. They find that sectors with a middle level of technology and sectors located in the middle region of Turkey are more successful in creating jobs for the Turkish labor force. Dine (2019) provides 
evidence of backward linkage on the growth in employment in Turkish manufacturing sectors. He focuses on the input-output tables of the WIOD 2016 database (Timmer et al., 2015) and ignores possible transmission mechanisms such as foreign direct investment and tariffs in his model. In addition, his research focuses on labor market outcomes rather than manufacturing size. Hence, our paper aims to address this gap in the literature and provide an empirical contribution to the growing number of studies on trade and financial openness and the industrialization nexus.

In this study, we mainly try to answer two questions. One of them is whether Turkey has been experiencing the premature deindustrialization as Rodrik (2016) claims. The second is that given the arguments for the premature deindustrialization, what are the potential determinants of the lower levels of manufacturing employment and value added in comparison with service sectors? We basically follow the Rodrik (2016) study, conducting his analysis at the country level whereas we apply the analysis on the sectoral level, which allows us to take into account sectoral heterogeneity in datasets. To the best of our knowledge, there is no comprehensive sectoral study investigating the effects of various measures of trade openness on sectoral employment and real value added for Turkey. Our estimation results suggest that Turkey has not experienced deindustrialization over the periods of 1995-2009 and 2005-2014. Hence, we can conclude that Turkey is not on the deindustrialization track.

After liberalization efforts in the 1980s and the EU Customs Union in 1995, Turkish sectors entered into a new era. This is especially valid for the exporter industries. Hence, further analysis needs to be done to shed light on this subject. Our estimates indicate that backward participation decreases the employment and value added shares of the manufacturing sector. Other openness measurements such as import shares, imposed tariffs, and FDI inflows have also adverse effects. Moreover, especially the net exporter manufacturing industries have significant increases in their value added shares and significant decreases in their employment shares, which provides little evidence for the employment deindustrialization for Turkey.

As can be seen from Figure 1, the Turkish manufacturing sector experiences an increase in the absolute size of its labor force and accounts for a significant share of total Turkish employment during the period 1970-2018. Nevertheless, its share of total employment is less than that of service sectors. While the share of manufacturing sector employment has risen from $11.4 \%$ to $19.7 \%$, the share of the service sector has risen from $19.5 \%$ to $54.9 \%$. Sevinç et al. (2018) argue that during the period $1995-2000$, while $61 \%$ of internally migrated individuals are employed 
in the manufacturing sector, $15 \%$ of them are employed in service sectors. This may be due to the low potential of manufacturing sectors to create new jobs or to the lack of qualifications and technical knowledge of migrants that the manufacturing sectors seek. At the same time, during the period 1969-2018, Figure 2 indicates that the share of manufacturing value added reached its maximum value, 23\%, in 1989, and then especially the period between 1997 and 2010, the share followed a decreasing trend. This may be a sign of premature deindustrialization. However, for the last decade, the trend shows an increasing slope. In the same period, growths of exports and imports by $10 \%$ and $11.3 \%$, respectively indicate the integration of the country into the global economy (TURKSTAT, 2019). Therefore, the de/industrialization process cannot be considered as independent from internationalization.

\section{Put Figure 1 about here}

\section{Put Figure 2 about here}

This study is organized as follows. In the next section, the dataset we used is explained. The third section presents the methodology and empirical models. The fourth section answers whether or not a premature deindustrialization exists in Turkey and provides an empirical approximation of the causes of a possible deindustrialization trend. Finally, the fifth section concludes by providing strategic policy recommendations for the Turkish sectors.

\section{Data}

We basically employ four main databases: WIOD, World Input Output Database, 2014 and 2016 (Timmer et al., 2015); OECD-TiVA, Trade in Value Added, 2016 (WTO/OECD, 2016) and 2018 (OECD, 2019a); WITS, World Integrated Trade Solution (2019); and CBRT, Central Bank of Republic of Turkey (2019) containing data on both manufacturing and service sectors. Note that since OECD-TiVA 2016 and 2018 editions and WIOD 2014 and 2016 editions are not fully compatible, we have two sets of estimates. In the first one, industries of the OECD 2016 edition are matched with that of the WIOD 2014 edition. The time span of this dataset is between the years 1995 and 2009. In the second one, industries of the OECD 2018 edition are matched with that of the WIOD 2016 edition. The time span of this dataset is between the years 2005 and 2014. The industries in both CBRT (2019) and WITS (2019) are compatible with these two composed samples. The matching strategy of industry codes is given in Appendix Table A1. In WIOD and the SEA (Socio Economic Accounts) databases (Timmer et al., 2015), 
number of employees and capital stock are the variables we used in our analysis. ${ }^{1}$ Capital stocks in the national local currencies are converted into US dollars.

In the OECD-TiVA, 2016 and 2018 editions, measures of sectoral gross exports, imports, global value chain $(\mathrm{GVC})$ participation, sectoral value added are also utilized. ${ }^{2}$ Regarding the GVC participation indices, the OECD 2016 release starts to use new participation indices based on final demand that are different from previous indices based on value added shares in gross exports (Koopman et al., 2010). In the OECD 2016 release, the share of foreign value-added in domestic final demand and the share of domestic value-added used in production for foreign final demand are employed as backward and forward participation indices, respectively. These new indices are superior to the common indices especially in industry level analysis since the previous participation indices may be very high (much higher than 100\%) if the sectors have very little direct exports.

The WITS (2019) database provides average tariff rates weighted by their corresponding trade value of both Turkey imposes and Turkey faced. ${ }^{3}$ Kowalski et al. (2015) also utilize weighted averages for tariffs in their study. Sectoral foreign direct investment inflow and outflow variables are directly taken from CBRT (2019). These variables in the national local currency are converted to US dollars. All nominal variables are deflated using the price index given via WIOD databases (Timmer et al., 2015).

The matching strategy of these four datasets is based on official OECD-TiVA, 2016 and 2018 reports, WIOD, 2014 and 2016 reports, WITS (2019) sectoral codes based on ISIC3 sector classification, and CBRT data information documents. Overall, after carefully matching each industry one by one by utilizing the four databases above, we have 24 sectors $^{4}$ for the first sample and 25 sectors for the second sample. Among them, one is agriculture, one is construction, twelve are manufacturing, and eleven are service sectors. In order to make clear comparison between manufacturing and service sectors, we drop the agriculture and construction sectors from our operational samples. We thus have 15 years and 22 sectors in the first, 10 years and 23 sectors in the second sample.

The following four figures below are directly taken from these two samples. Figure 3 indicates that the manufacturing sector has a stable trend for the period. The share of the service sector

\footnotetext{
${ }^{1}$ The data are available on http://www.wiod.org

${ }^{2}$ WTO/OECD (2016) and OECD (2019a)

${ }^{3}$ The data are available on http://wits.worldbank.org

${ }^{4}$ One sector does not match with WIOD sector codes, so we dropped this sector from the analysis.
} 
has been increased over the years, from approximately $50 \%$ to $60 \%$. On the other hand, Figure 4 displays the value added shares of sectors, indicating the widening gap between manufacturing and services.

Figure 5 indicates a slightly declining trend in the manufacturing sector starting from the year 2008. In fact, other sectors show a clear stable path during the period. Figure 6 regarding value added shares of sectors shows a stable gap between manufacturing and services.

Overall, starting in the year 1995, the declining trend in employment level in the manufacturing sector has been stabilized over the period 2002 and 2008, after that it pursues its declining trend again. The value added share declines over the period 1995-2002, but it is relatively smooth after the year 2002. Hence, based on the raw data, we have suspicions concerning the process of deindustrialization in the Turkish manufacturing sectors.

Put Figure 3 about here

Put Figure 4 about here

Put Figure 5 about here

Put Figure 6 about here

The descriptive statistics of all variables we employ in the analysis are given in Table 1 for two separate datasets, respectively.

Put Table 1 about here

\section{Empirical Methodology}

For both of the samples, the following empirical models are estimated utilizing the Least Squares Dummy Variables (LSDV) estimation technique for manufacturing and service sectors separately to investigate the association between deindustrialization and trade/financial openness. We use employment shares and value added shares as the two measures of deindustrialization.

$E S_{i, t}=\beta_{0}+\beta_{1} K_{i, t}+\beta_{2} K_{i, t}^{2}+\beta_{3} L P_{i, t}+\beta_{4} L P_{i, t}^{2}+\beta_{5} O P E N 1_{i, t}+\beta_{6} O P E N 2_{i, t}+\beta_{7} D_{i, t}+\beta_{8} S_{i, t}+\mathcal{E}_{i, t}$

In the equation above, $i$ represents sectors and $t$ represents time. $E S_{i, t}$ is the employment share of sectors in total employment. $K_{i, t}$ is the natural logarithm of capital stock. $L P_{i, t}$ is labor productivity measured by the natural logarithm of the value added per employee. Following 
Rodrik's model $(2016)^{5}$, we also include the square terms of main variables because scatter plots suggest that employment shares decrease across modest levels of labor productivity, but then increase once sectors have higher labor productivity. $K^{2}{ }_{i, t}$ is the square of variable $K_{i, t}$ and $L P^{2}{ }_{i, t}$ is the square of the variable $L P_{i, t} . O P E N 1_{i, t}$ is the vector containing a set of variables. These are imports which are the ratio coming from dividing gross imports by value added; the tariff rate which Turkey imposes; the backward GVC participation ratio; and FDI inflow which is the ratio calculated by dividing foreign direct investment inflows by value added. OPEN2 $2_{i, t}$ is the vector containing a set of variables. These are exports which is the ratio coming from dividing exports by value added; tariff rates which Turkey faced; the forward GVC participation ratio; and FDI outflows which is the ratio calculated by dividing foreign direct investment outflows by value added. $D_{i, t}$ is the dummy variable for years. $S_{i, t}$ is the dummy variable for sectors. The sign of $\beta_{7}$ provides information whether deindustrialization exists or not. $\beta_{5}$ and $\beta_{6}$ capture the effects of different measurement of trade/financial openness to deindustrialization.

$V A S_{i, t}=\beta_{0}+\beta_{1} K_{i, t}+\beta_{2} K_{i, t}^{2}+\beta_{3} E M P_{i, t}+\beta_{4} E M P^{2}{ }_{i, t}+\beta_{5} O P E N 1_{i, t}+\beta_{6} O P E N 2_{i, t}+\beta_{7} D_{i, t}+\beta_{8} S_{i, t}+\mathcal{E}_{i, t}$

In the Equation 2 above, $V A S_{i, t}$ is the share of value added of each sector in total value added. $E M P_{i, t}$ is the natural logarithm of employees. We also include the square terms of main variables because scatter plots suggest that value added shares increase across modest levels of employment but then fall once sectors have higher employment level. The meanings of other variables and coefficients are the same with Equation 1.

\section{Results}

To investigate the issue of deindustrialization and the possible channels, we look at the relationship between sectoral employment/value added shares and variables representing trade and financial openness. The LSDV estimation technique is applied on two samples. Tables 2 and 3 present the results for the first sample and Tables 4 and 5 are for the second sample.

Table 2 reports the relationship between employment shares and trade/financial openness for both manufacturing and service sectors. As Rodrik (2016) suggests, we first look at the

\footnotetext{
${ }^{5}$ Our dependent variables are the exactly same as in the Rodrik's model. In his country level model, population and GDP are used as explanatory variables for representing sources of countries. Since we conduct sectoral level analysis, we employ capital stock and labor productivity (see, Abel et al. (2008) and Gordon (1995) for the theoretical foundation of the linkage between labor productivity and employment) in our first model and capital stock and employment level in the second model for representing sources/factor contents of sectors.
} 
estimated coefficients of the year dummies. The positive and significant coefficients for year dummies indicate that both manufacturing and service sectors have increases in employment shares through time. In fact, the increase in employment level of service sectors is slightly higher than the increase in employment level of manufacturing sectors. Therefore, over the years 1995-2009, we fail to observe employment deindustrialization. We then add openness variables to the estimates, measuring the effects of trade and financial liberalization on employment shares.

The estimation results in Table 2 show that there is no significant relationship between capital stock and manufacturing employment shares. If the productivity of workers rises, manufacturing employment decreases and then increases through time. Exports are positively and significantly associated with the manufacturing employment, which suggests that if exports increase by 1 percent, manufacturing employment shares increase by $0.3 \%$. Imports and backward participation are negatively related to both manufacturing and service employment shares. Regarding tariff rates, tariffs Turkey imposes are negatively associated with employment share of the manufacturing sector driven by the net exporters among the manufacturing sector. The one possible explanation is switching production towards more capital-intensive production techniques or increasing productivity in these protected manufacturing sectors. FDI inflows are also negatively and significantly associated with both the manufacturing and service employment shares. In fact, when we divide our samples into two groups as net exporters and net importers ${ }^{6}$, the effect of FDI inflows turns out to be positive for manufacturing sectors which are net exporters but still negative for manufacturing sectors which are net importers. For the service sector, the negative coefficient loses its significance for the net exporters, but the significance and negative sign persists for the net importers.

Table 3 presents the regression results for the value added shares for both manufacturing and service sectors, separately. The time dummies are positive for manufacturing and negative for services, but they are all insignificant. Thus, we do not find evidence for output deindustrialization. Therefore, over the years 1995-2009, we fail to observe any employment deindustrialization or output deindustrialization. In fact, when we undertake the analysis for the net exporters, employment deindustrialization is observed for them.

\section{Put Table 2 about here}

\footnotetext{
${ }^{6}$ We define a net exporter as follows: If a sector's gross export average by years is higher than or equal to the gross import average, this sector is then classified as a net exporter, otherwise as a net importer. For the space considerations, estimates for the net exporters/importes are not reported but available upon request.
} 


\section{Put Table 3 about here}

The results in Table 3 also show that there is no significant relationship between the capital stock and manufacturing value added shares, but value added shares of service sectors have an inverse U-shape when capital stock increases. For manufacturing, value added shares have a U-shape with respect to employment. Gross exports are negatively and significantly associated with value added shares. This may be explained by declining price levels of manufacturing products in developed countries. Since these price movements are transmitted into the Turkish markets, even if the quantity of manufacturing goods sold increases, this cannot generate an increase in value added because of inelastic demand for the Turkish manufacturing goods in international markets. This is because of the fact that production increases and then employment increases, (see, Table 2) whereas value added declines. Furthermore, this situation could be the result of the 1995 EU Customs Union, which can be seen as a shock to the Turkish economy because our first dataset starts from the year 1995. Regarding the other openness measures, imports, backward participation, and FDI inflows are negatively associated with value added share of both manufacturing and services. In addition, forward participation rate raises the share of manufacturing value added as expected. For services which are net exporters, this effect is also positive. Moreover, even if tariffs have no significant impacts on the total manufacturing sample, for the net exporters there is a significant and positive relationship between tariff rates which Turkey imposes and manufacturing value added shares.

Tables 4 and 5 present the regression results of employment and value added shares for the second time period, 2005-2014, respectively. In Table 4, the time dummies are negative, but they are mostly insignificant for manufacturing sectors. However, time dummies are mostly negative and significant for service sectors. Even if we observe employment deindustrialization for the net exporter manufacturing sectors, the overall effect is not significant. In fact, we do not find strong evidence for deindustrialization except for the net exporter manufacturing industries. Therefore, over the years 2005-2014, we do not observe any employment deindustrialization.

The results also show that exports and value added exports have positive associations with manufacturing employment shares. This is a similar trend of what we observe in Table 2 . The estimated results on backward participation are very robust and negatively affect both manufacturing and service employment shares. For service sectors, exports, value added export, and FDI inflows have negative associations with employment shares. 


\section{Put Table 4 about here}

\section{Put Table 5 about here}

Table 5 presents the regression results for the value added shares of the both manufacturing and service sectors. While the time dummies are all insignificant for manufacturing sectors, they are significantly negative for services. Therefore, over the years 2005-2014, these results fail to provide overall evidence for employment deindustrialization or output deindustrialization.

Our estimations also show that there is no significant relationship between capital stock and manufacturing value added shares. For manufacturing sectors, value added shares have a Ushape with respect to employment shares. Regarding the openness measures, exports, imports, and backward participation are negatively associated with the value added share of both manufacturing and services. In fact, the negative association between value added and exports, but the positive association between employment and exports can be a sign of the weaknesses of Turkish manufacturing sectors in international markets. In general, a lack of positive relationship between foreign direct investment and our dependent variables is consistent with the Turkish case because many other studies find no or a negative relationship between foreign direct investment and employment or growth (Ekinci 2011; Göçer and Peker, 2014; Hisarciklilar et al., 2014).

\section{Conclusion}

This study mainly explores the following two arguments. One of them is whether Turkey has been experiencing premature deindustrialization. The second is that given the discussion on premature deindustrialization such as employment and output deindustrialization, what are the determinants of manufacturing employment and value added shares in comparison to service sectors? In order to understand the issue in a comprehensive way and beyond some descriptive analyses, we employ very rich datasets taken from various sources. We then apply the Least Squares Dummy Variables estimation technique on two different samples: the first containing 15 years and 22 sectors and the second containing 10 years and 23 sectors.

After the major shift in financial openness in the late 1980s and the European Customs Union in 1995, eye inspection of the raw data indicates that Turkish sectors seemed to enter into the new era, but this deindustrialization period lasted for a very short period of time. Our estimation results find an increase in manufacturing employment shares in the earlier sample and decrease in manufacturing employment shares over 2012-2014 in the later sample. There is a very stable 
manufacturing value added shares in both samples. Therefore, neither employment deindustrialization nor output deindustrialization for the two periods are observed, which suggests no evidence for deindustrialization in Turkey. Moreover, for both periods, the net exporter manufacturing industries face a significant increase in their value added shares and a significant decrease in their employment shares, which suggests employment deindustrialization for Turkey. However, this negative effect disappears in the overall results. Hence, we then investigate the determinants of sectoral employment and value added shares. Our results provide very interesting results on the subject. Regarding trade shares, there is a positive employment effect on exports and negative employment and output effects on import for the two periods. Regarding tariffs, there is a negative effect on tariff rates Turkey imposes on employment shares of manufacturing and a positive effect on value added shares in the first sample. Regarding GVC participations, there is a negative effect on backward GVC participation in both samples and all specifications. This might be the result of the fact that the backward participation has increased by 2.5 times from 1998 to 2011 (WTO/OECD, 2016) and manufacturing sectors are highly dependent on foreign inputs. Regarding FDI flows, there are not any effects on manufacturing employment and value added shares. Therefore, effectively designing and implementing openness policies to integrate with the world economy to benefit from globalization is extremely important.

Acknowledgements: The first author acknowledges support from the Turkish Academy of Sciences.

Conflicts of Interest: The authors declare that there is no conflict of interest regarding the publication of this article. 


\section{References}

Abel, A., Bernanke, B., \& Croushore, D. (2008). Macroeconomics (6th ed.). Boston, MA: Pearson, Addison-Wesley.

Ahsan, R. N., \& Mitra, D. (2014). Trade liberalization and labor's slice of the pie: Evidence from Indian firms. Journal of Development Economics, 108, 1-16.

Bamber, P., \& Gereffi, G. (2013). Costa Rica in the medical devices global value chain. Durham: Duke University, Center on Globalization, Governance and Competitiveness, 1-63.

Banga, K. (2016). Impact of global value chains on employment in India. Journal of Economic Integration, 31(3), 631-673.

Bogliaccini, J. A. (2013). Trade liberalization, deindustrialization, and inequality: evidence from middle-income Latin American countries. Latin American Research Review, 79105.

Boratav, K. (2016). The Turkish bourgeoisie under neoliberalism. Research and Policy on Turkey, 1(1), 1-10.

Castillo, M., \& Martins, A. (2016). Premature deindustrialization in Latin America. Production Development Series, ISSN 1020-5179, 1-29.

CBRT. (2019). International Investment Position Statistics. https://evds2.tcmb.gov.tr/index.php?/evds/serieMarket/collapse_18/5003/DataGroup/e nglish/bie_uypucay/

Dincer, N., \& Tekin-Koru, A. (2019). The Effect of Border Barriers to Services Trade on Goods Trade, The World Economy, 1-26.

Dine, M. N. (2019). Impact of Global Value Chains' Participation on Employment in Turkey and Spillovers Effects. Journal of Economic Integration, 34(2), 308-326.

Ekinci, A. (2011). Doğrudan yabancı yatırımların ekonomik büyüme ve istihdama etkisi: Türkiye uygulaması (1980-2010). Eskişehir Osmangazi Üniversitesi İktisadi ve İdari Bilimler Dergisi, 6(2), 71-96.

Erumban, A.A., Gouma, R., de Vries, G., de Vries, K., Timmer, M. (2012). "WIOD SocioEconomic Accounts (SEA): Sources and Methods", http://www.wiod.org/publications/source_docs/SEA_Sources.pdf (accessed on 20.07.2019).

Fernandes, A. (2003). Trade policy, trade volumes, and plant-level productivity in Colombian manufacturing industries: The World Bank, 1-43.

Ferreira, P. C., \& Rossi, J. L. (2003). New evidence from Brazil on trade liberalization and productivity growth. International Economic Review, 44(4), 1383-1405.

Firpo, S. P., \& Pieri, R. G. d. (2013). Structural change, productivity growth and trade policy in Brazil. Sao Paulo School of Economics Working Paper Series, 337, 1-32. 
Gordon, R. J. (1995). Is there a tradeoff between unemployment and productivity growth? (No. w5081). National Bureau of Economic Research.

Gouma, R., Timmer, M., de Vries, G. (2014). "Employment and Compensation in the WIOD Socio-Economic Accounts (SEA): Revisions for 2008/2009 and new data for 2010/2011", http://www.wiod.org/protected3/data13/update_sep12/SEA\%20Sources_June2014.pd f (accessed on 20.07.2019).

Gouma, R., Chen, W., Woltjer, P., Timmer, M.(2018). "WIOD Socio-Economic Accounts 2016: Sources and Methods", http://www.wiod.org/protected3/data16/SEA/SEA16_Sources.pdf (accessed on 20.07.2019).

Göçer, İ., \& Peker, O. (2014). Yabancı doğrudan yatırımların istihdam üzerindeki etkisi: Türkiye, çin ve hindistan örneğinde çoklu yapısal kırılmalı eşbütünleşme analizi. Yönetim ve Ekonomi: Celal Bayar Üniversitesi İktisadi ve İdari Bilimler Fakültesi Dergisi, 21(1), 107-123.

Hisarciklilar, M., Gultekin-Karakas, D., \& Asici, A. A. (2014). Can FDI be a panacea for unemployment?: The Turkish case. In Labor and employment relations in a globalized world (pp. 43-70). Springer, Cham.

Jenkins, R. (2015). Is Chinese competition causing deindustrialization in Brazil? Latin American Perspectives, 42(6), 42-63.

Koopman, R., Powers, W., Wang, Z. and Wei, S-J. (2010), "Give Credit Where Credit Is Due: Tracing Value Added in Global Production Chains", National Bureau of Economic Research (NBER) Working Paper No: 16426, http://www.nber.org/papers/w16426.pdf

Kowalski, P., Gonzalez, J. L., Ragoussis, A., \& Ugarte, C. (2015). Participation of developing countries in global value chains. OECD Trade Policy Papers, No. 179, OECD Publishing, Paris, 1-171.

López, M. H. (2017). Trade liberalization and premature deindustrialization in Colombia. Journal of Economic Structures, 6(1), 1-30.

McMillan, M. S., \& Rodrik, D. (2011). Globalization, structural change and productivity growth. (No. w17143). National Bureau of Economic Research, 1-54.

Meçik, O., \& Aytun, U. (2018). Türkiye ekonomisinde erken sanayisizleşmeye bölgesel bir yaklaşım. METU Studies in Development, 45(1), 59-81.

Menezes-Filho, N. A., \& Muendler, M.-A. (2011). Labor reallocation in response to trade reform. (No. w17372). National Bureau of Economic Research, 1-50.

OECD (2016), "Global Value Chains and Trade in Value- Added: An Initial Assessment of the Impact on Jobs and Productivity", OECD Trade Policy Papers, No. 190, OECD Publishing, Paris. http://dx.doi.org/10.1787/5jlvc7sb5s8w-en (accessed on 21.07.2019) 
OECD (2019a). "Trade in value added", OECD Statistics on Trade in Value Added (database), https://doi.org/10.1787/data-00648-en (accessed on 19.07.2019).

OECD (2019b). "STAN Industry ISIC Rev. 4", STAN: OECD Structural Analysis Statistics (database), http://www.oecd.org/sti/ind/stanstructuralanalysisdatabase.htm (accessed on 20.07.2019).

Dehejia, R. \& Panagariya, A. (2014). Trade Liberalization in Manufacturing and Accelerated Growth in Services in India. NBER Working Paper Series, 1-66.

Rasiah, R. (2011). Is Malaysia facing negative deindustrialization? Pacific Affairs, 84(4), 714735.

Rodrik, D. (2016). Premature deindustrialization. Journal of Economic Growth, 21(1), 1-33.

Sevinç, G., Davran, M. K., \& Sevinç, M. R. (2018). Türkiye'de Kırdan Kente Göç ve Göçün Aile Üzerindeki Etkileri. İktisadi İdari ve Siyasal Araştırmalar Dergisi, 3(6), 70-82.

Turco, A. L., \& Maggioni, D. (2013). Does trade foster employment growth in emerging markets? Evidence from Turkey. World Development, 52, 1-18.

$\begin{array}{lllll}\text { TURKSTAT. } & \text { (2019). } & \text { Foreign } & \text { Trade }\end{array}$ http://www.tuik.gov.tr/PreTablo.do?alt_id=1046

Wang, Z., Wei, S-J., Yu, X. and Zhu, K. (2017), "Measures of Participation in Global Value Chains and Global Business Cycles, National Bureau of Economic Research (NBER) Working Paper No: 23222, http://www.nber.org/papers/w23222.pdf

Timmer, M. P., Dietzenbacher, E., Los, B., Stehrer, R. and de Vries, G. J. (2015), "An Illustrated User Guide to the World Input-Output Database: the Case of Global Automotive Production", Review of International Economics., 23: 575-605.

WITS (2019). "Tariff and Trade Analysis Database", World Integrated Trade Solution, https://wits.worldbank.org/ (20.07.2019).

WTO/OECD (2016). "Trade in value added (Edition 2016)", OECD-WTO: Statistics on Trade in Value Added (database), https://doi.org/10.1787/2644abe4-en (accessed on 17.07.2019). 


\section{Figures and Tables}

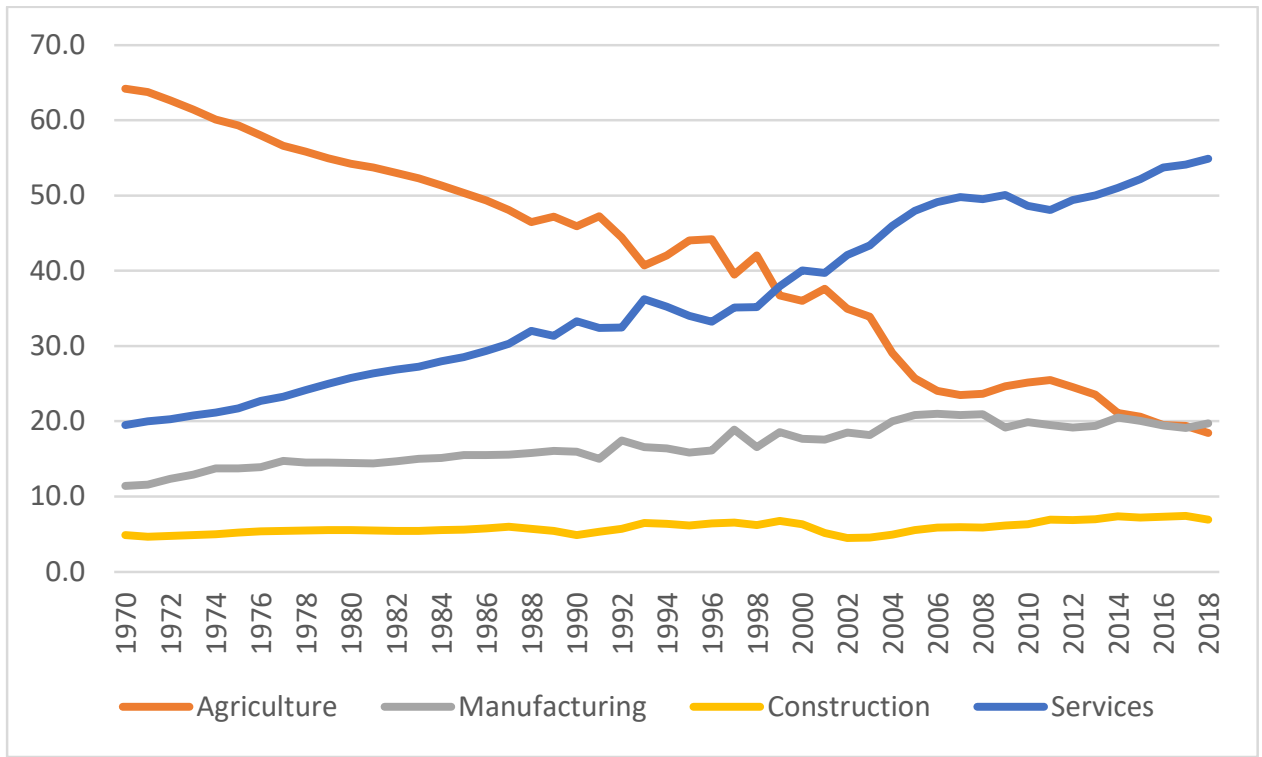

Figure 1: Employment shares by sectors, 1970-2018

Source: EVDS, Central Bank of the Republic of Turkey

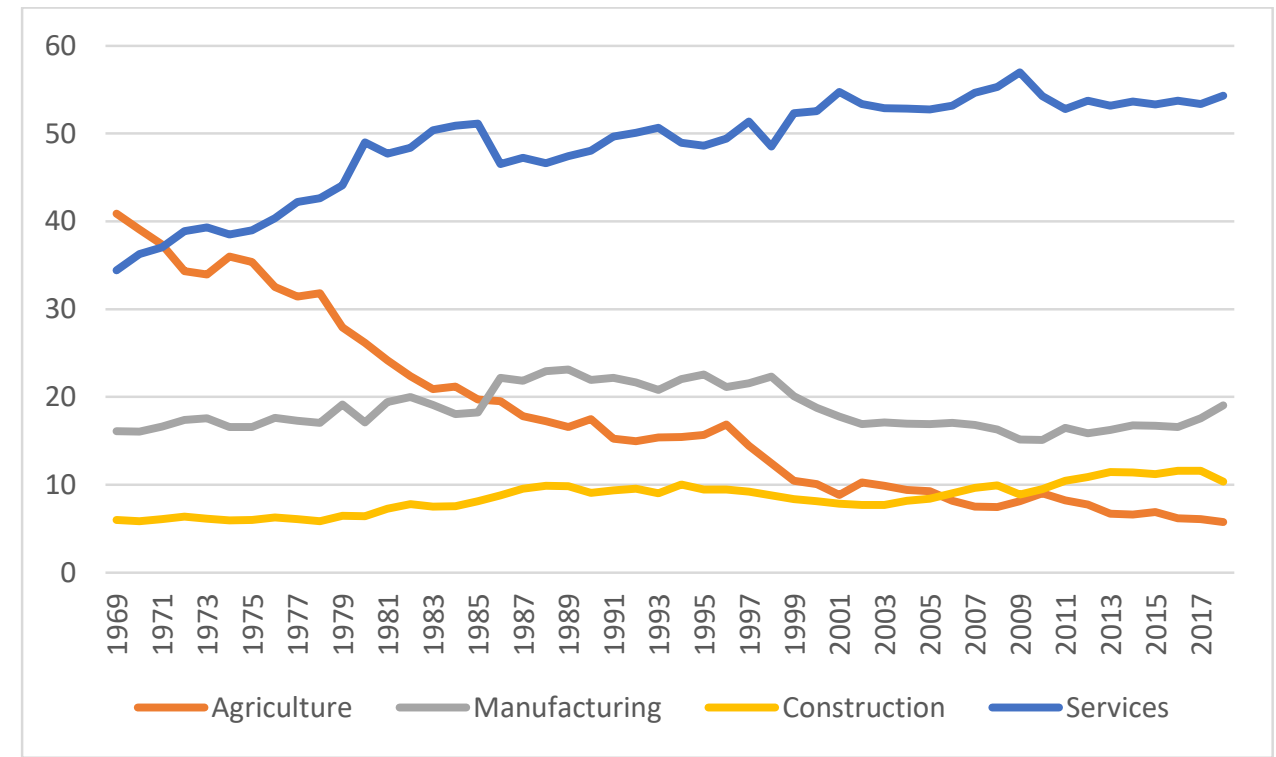

Figure 2: Value added shares by sectors, 1969-2018

Source: World Development Indicators, World Bank 


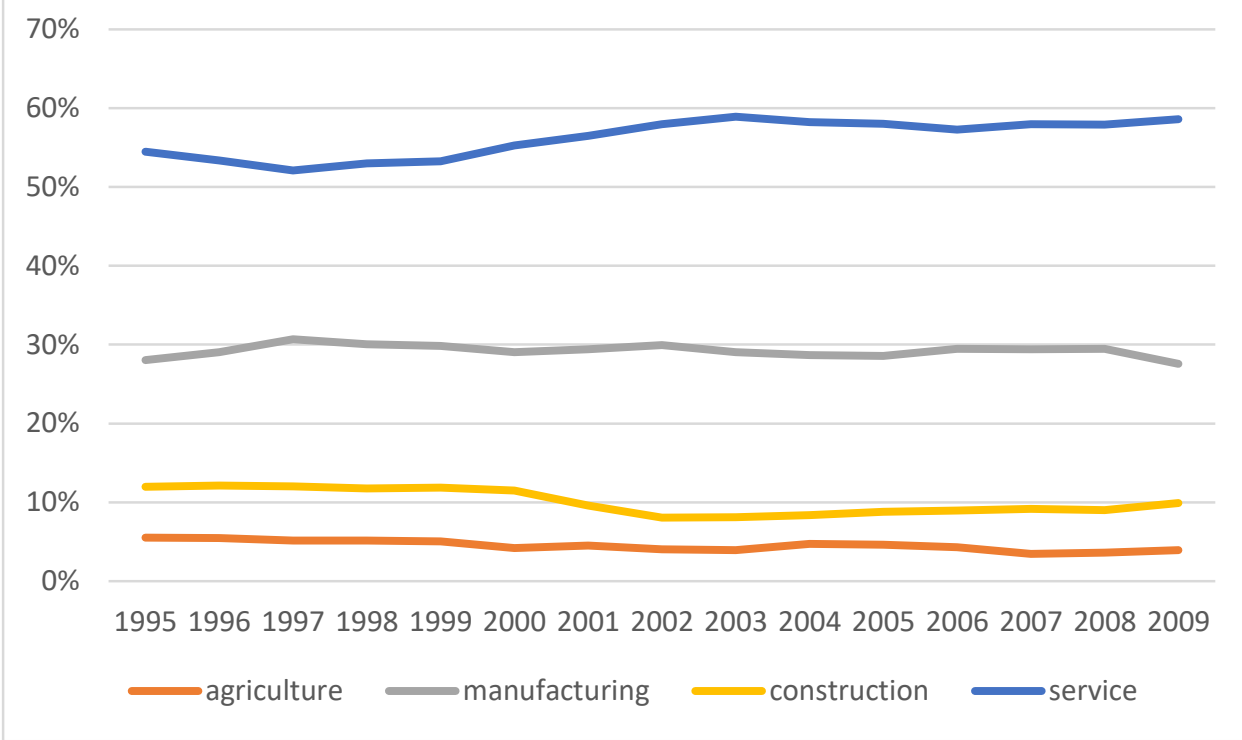

Figure 3: Employment shares by sectors, 1995-2009

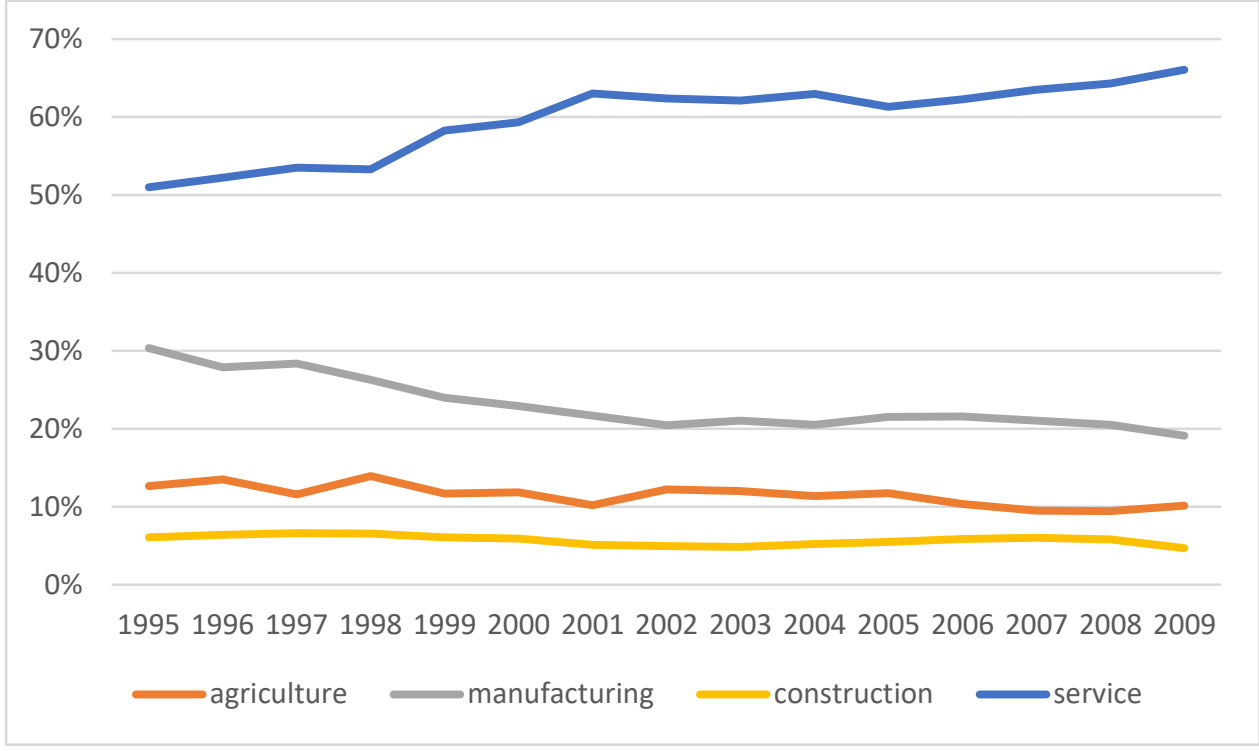

Figure 4: Value added shares by sectors, 1995-2009 


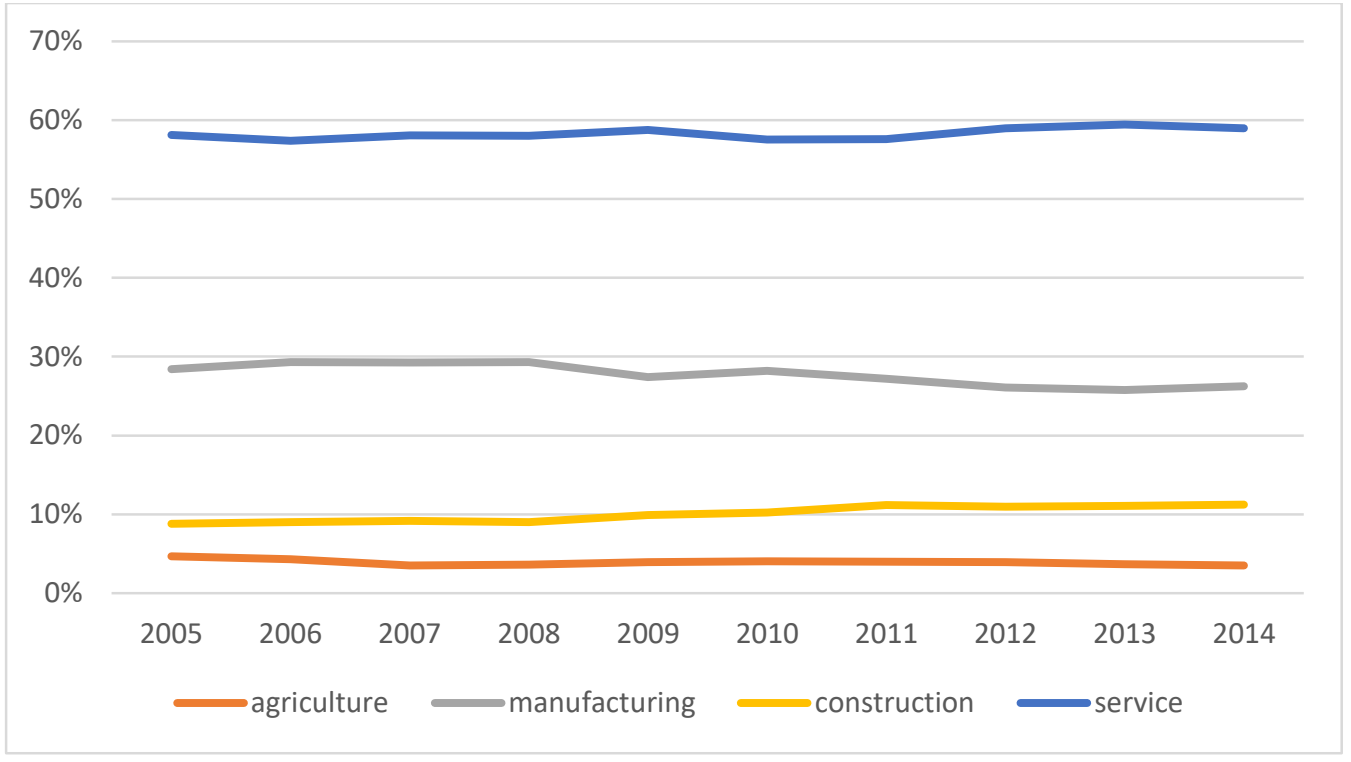

Figure 5: Employment shares by sectors, 2005-2014

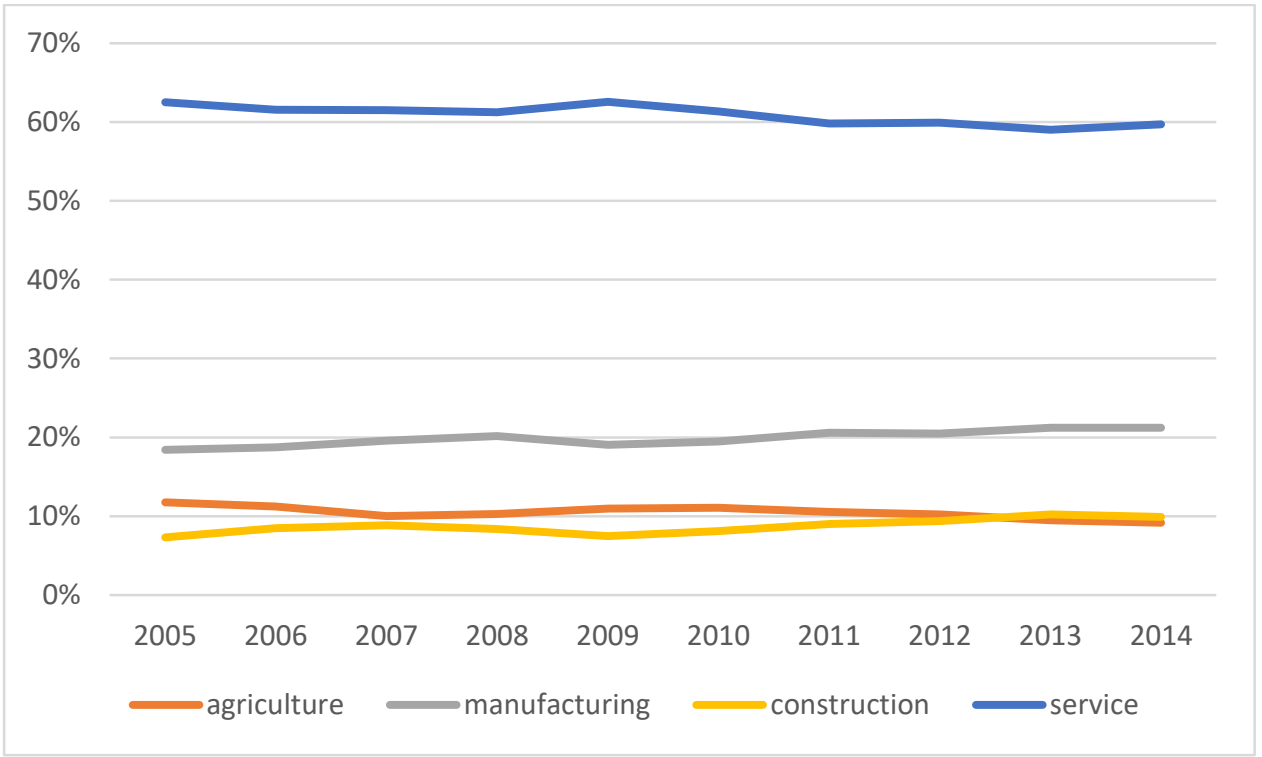

Figure 6: Value added shares by sectors, 2005-2014 
Table 1: Summary Statistics: 1995-2009 and 2005-2014

\begin{tabular}{|c|c|c|c|c|c|c|c|c|c|c|c|c|}
\hline \multirow[b]{3}{*}{ Variables } & \multicolumn{6}{|c|}{ First Sample } & \multicolumn{6}{|c|}{ Second Sample } \\
\hline & \multicolumn{2}{|c|}{ Manufacturing } & \multicolumn{2}{|c|}{ Services } & \multicolumn{2}{|c|}{ Total } & \multicolumn{2}{|c|}{ Manufacturing } & \multicolumn{2}{|c|}{ Services } & \multicolumn{2}{|c|}{ Total } \\
\hline & \# of Obs. & Mean & $\begin{array}{l}\text { \# of } \\
\text { Obs. }\end{array}$ & Mean & $\begin{array}{l}\text { \# of } \\
\text { Obs. }\end{array}$ & Mean & \# of Obs. & Mean & \begin{tabular}{|l|}
$\#$ of \\
Obs.
\end{tabular} & Mean & $\begin{array}{l}\text { \# of } \\
\text { Obs. }\end{array}$ & Mean \\
\hline Employment shares & 180 & 0.02 & 150 & 0.06 & 330 & 0.04 & 120 & 0.02 & 110 & 0.05 & 230 & 0.04 \\
\hline Value added shares & 180 & 0.02 & 150 & 0.06 & 330 & 0.04 & 120 & 0.02 & 110 & 0.06 & 230 & 0.04 \\
\hline $\ln ($ employees $)$ & 180 & 12.02 & 150 & 12.75 & 330 & 12.35 & 120 & 12.14 & 110 & 12.84 & 230 & 12.48 \\
\hline $\begin{array}{l}\ln (\text { value added per } \\
\text { worker) }\end{array}$ & 180 & 10.37 & 150 & 10.45 & 330 & 10.41 & 120 & 10.68 & 110 & 10.85 & 230 & 10.76 \\
\hline $\ln ($ capital stock $)$ & 180 & 20.39 & 150 & 20.69 & 330 & 20.53 & 120 & 23.74 & 110 & 23.77 & 230 & 23.76 \\
\hline Export/Value added & 180 & 0.55 & 150 & 0.13 & 330 & 0.36 & 120 & 0.75 & 110 & 0.10 & 230 & 0.44 \\
\hline Import/Value added & 180 & 1.01 & 150 & 0.06 & 330 & 0.58 & 120 & 1.40 & 110 & 0.06 & 230 & 0.76 \\
\hline $\begin{array}{l}\text { Tariff rates Turkey } \\
\text { imposes }\end{array}$ & 180 & 0.04 & 150 & 0.00 & 330 & 0.02 & 120 & 0.04 & 110 & 0.00 & 230 & 0.02 \\
\hline $\begin{array}{l}\text { Tariff rates Turkey } \\
\text { faced }\end{array}$ & 180 & 0.06 & 150 & 0.00 & 330 & 0.03 & 120 & 0.05 & 110 & 0.00 & 230 & 0.03 \\
\hline Backward participation & 180 & 0.38 & 150 & 0.11 & 330 & 0.26 & 120 & 0.48 & 110 & 0.13 & 230 & 0.31 \\
\hline Forward participation & 180 & 0.28 & 150 & 0.13 & 330 & 0.21 & 120 & 0.32 & 110 & 0.21 & 230 & 0.27 \\
\hline Inflow/Value added & 180 & 0.01 & 150 & 0.02 & 330 & 0.02 & 120 & 0.02 & 110 & 0.06 & 230 & 0.04 \\
\hline Outflow/Value added & 180 & 0.00 & 150 & 0.00 & 330 & 0 & 120 & 0.01 & 110 & 0.00 & 230 & 0.01 \\
\hline
\end{tabular}


Table 2: Employment shares, 1995-2009

\begin{tabular}{|c|c|c|c|c|c|c|c|c|c|}
\hline \multirow{2}{*}{$\begin{array}{l}\text { Employment shares } \\
\text { VARIABLES }\end{array}$} & \multicolumn{5}{|c|}{ MANUFACTURING } & \multicolumn{4}{|c|}{ SERVICE } \\
\hline & $(1)$ & $(2)$ & (3) & $(4)$ & $(5)$ & $(1)$ & $(2)$ & (3) & $(4)$ \\
\hline In(capital) & $\begin{array}{c}0.014 \\
(0.011)\end{array}$ & $\begin{array}{c}0.011 \\
(0.011)\end{array}$ & $\begin{array}{c}0.015 \\
(0.012)\end{array}$ & $\begin{array}{c}0.001 \\
(0.011)\end{array}$ & $\begin{array}{c}0.013 \\
(0.011)\end{array}$ & $\begin{array}{l}0.020^{* *} \\
(0.009)\end{array}$ & $\begin{array}{c}0.005 \\
(0.007)\end{array}$ & $\begin{array}{l}-0.005 \\
(0.007)\end{array}$ & $\begin{array}{c}0.011 \\
(0.009)\end{array}$ \\
\hline Square of In(capital) & $\begin{array}{l}-0.000 \\
(0.000)\end{array}$ & $\begin{array}{l}-0.000 \\
(0.000)\end{array}$ & $\begin{array}{l}-0.000 \\
(0.000)\end{array}$ & $\begin{array}{l}-0.000 \\
(0.000)\end{array}$ & $\begin{array}{l}-0.000 \\
(0.000)\end{array}$ & $\begin{array}{l}-0.000 \\
(0.000)\end{array}$ & $\begin{array}{c}0.000 \\
(0.000)\end{array}$ & $\begin{array}{l}0.000 * \\
(0.000)\end{array}$ & $\begin{array}{l}-0.000 \\
(0.000)\end{array}$ \\
\hline $\begin{array}{l}\text { In(value added per } \\
\text { worker) }\end{array}$ & $\begin{array}{c}-0.017^{* * *} \\
(0.005)\end{array}$ & $\begin{array}{c}-0.011 * * \\
(0.005)\end{array}$ & $\begin{array}{c}-0.013 * * * \\
(0.004)\end{array}$ & $\begin{array}{l}-0.006 \\
(0.007)\end{array}$ & $\begin{array}{c}-0.018 * * * \\
(0.005)\end{array}$ & $\begin{array}{c}-0.063 * * \\
(0.027)\end{array}$ & $\begin{array}{c}-0.067 * * \\
(0.027)\end{array}$ & $\begin{array}{c}-0.074 * * * \\
(0.026)\end{array}$ & $\begin{array}{c}-0.072 * * * \\
(0.027)\end{array}$ \\
\hline $\begin{array}{l}\text { Square of In(value added } \\
\text { per worker) }\end{array}$ & $\begin{array}{c}0.001 * * * \\
(0.000)\end{array}$ & $\begin{array}{c}0.000 \\
(0.000)\end{array}$ & $\begin{array}{c}0.000 * * \\
(0.000)\end{array}$ & $\begin{array}{l}-0.000 \\
(0.000)\end{array}$ & $\begin{array}{c}0.001 * * * \\
(0.000)\end{array}$ & $\begin{array}{l}0.002^{*} \\
(0.001)\end{array}$ & $\begin{array}{c}0.002 \\
(0.001)\end{array}$ & $\begin{array}{l}0.002^{*} \\
(0.001)\end{array}$ & $\begin{array}{c}0.002^{* *} \\
(0.001)\end{array}$ \\
\hline Import/Value added & & $\begin{array}{c}-0.002 * * * \\
(0.001)\end{array}$ & & & & & $\begin{array}{c}-0.083^{* *} \\
(0.034)\end{array}$ & & \\
\hline Export/Value added & & $\begin{array}{l}0.003^{*} \\
(0.001)\end{array}$ & & & & & $\begin{array}{l}-0.011 \\
(0.008)\end{array}$ & & \\
\hline Tariff Turkey imposes & & & $\begin{array}{c}-0.048^{* * *} \\
(0.016)\end{array}$ & & & & & & \\
\hline Tariff Turkey faced & & & $\begin{array}{c}0.002 \\
(0.017)\end{array}$ & & & & & & \\
\hline Backward participation & & & & $\begin{array}{c}-0.022^{* * *} \\
(0.004)\end{array}$ & & & & $\begin{array}{c}-0.128^{* * *} \\
(0.019)\end{array}$ & \\
\hline Forward participation & & & & $\begin{array}{c}0.007 \\
(0.007)\end{array}$ & & & & $\begin{array}{c}0.009 \\
(0.015)\end{array}$ & \\
\hline Inflow & & & & & $\begin{array}{l}-0.026^{*} \\
(0.014)\end{array}$ & & & & $\begin{array}{c}-0.023 * * * \\
(0.008)\end{array}$ \\
\hline Outflow & & & & & $\begin{array}{l}-0.027 \\
(0.031)\end{array}$ & & & & $\begin{array}{c}0.064 \\
(0.143)\end{array}$ \\
\hline \# of Observations & 180 & 180 & 180 & 180 & 180 & 150 & 150 & 150 & 150 \\
\hline
\end{tabular}

Notes: Robust standard errors in parentheses, $* * * p<0.01, * * p<0.05, * p<0.1$. Sector dummies are included in all specifications. The time dummies are all significantly positive in the first, third, and the fifth specifications and they are positive but insignificant in the second and fourth specifications for manufacturing sectors. The time dummies are all positive and significant in all specifications for service sectors. 
Table 3: Value added shares, 1995-2009

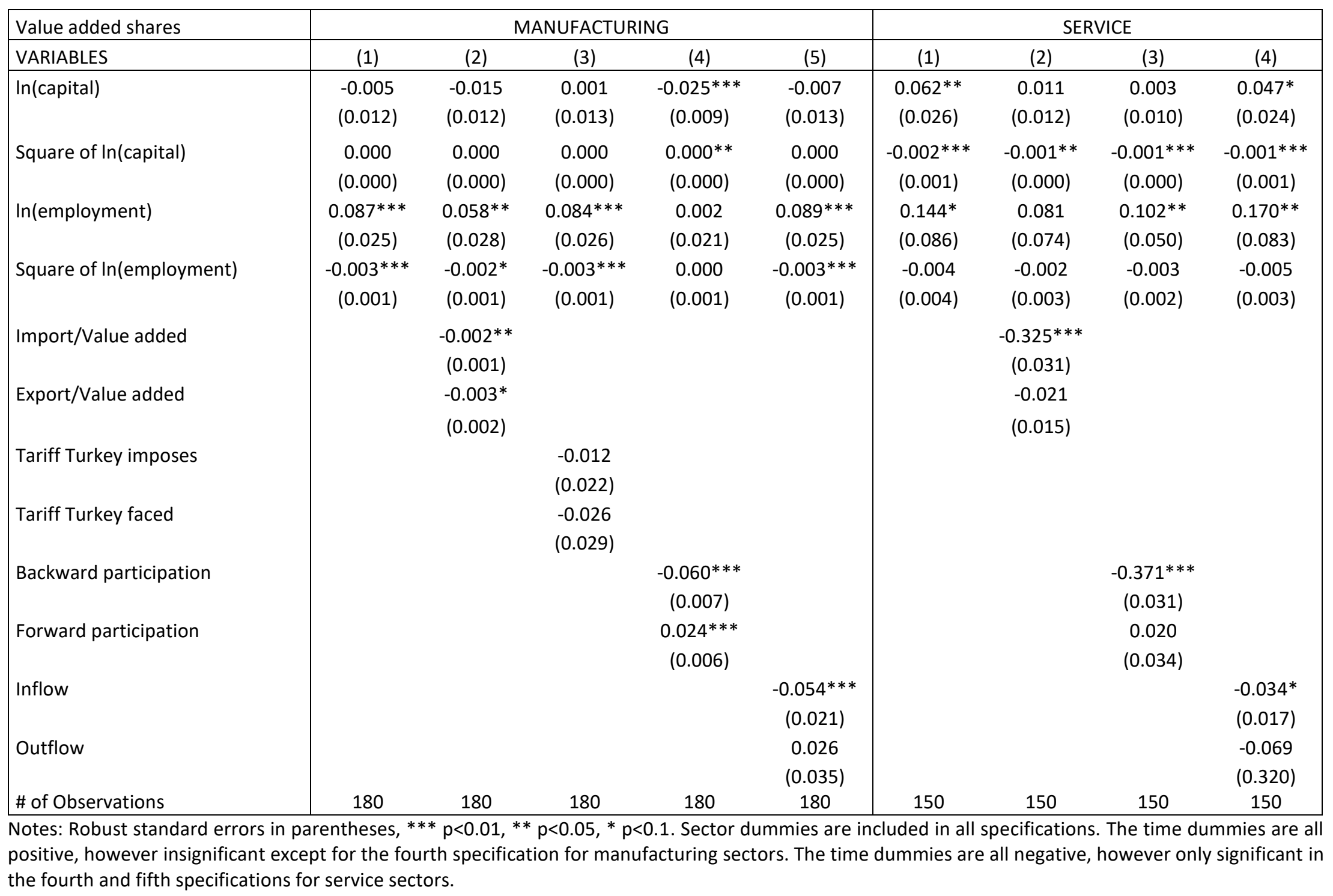


Table 4: Employment shares, 2005-2014

\begin{tabular}{|c|c|c|c|c|c|c|c|c|c|}
\hline \multirow{2}{*}{$\begin{array}{l}\text { Employment shares } \\
\text { VARIABLES }\end{array}$} & \multicolumn{5}{|c|}{ MANUFACTURING } & \multicolumn{4}{|c|}{ SERVICE } \\
\hline & (1) & $(2)$ & (3) & $(4)$ & (5) & $(1)$ & $(2)$ & (3) & (4) \\
\hline $\ln ($ capital) & $\begin{array}{l}-0.010 \\
(0.048)\end{array}$ & $\begin{array}{l}-0.036 \\
(0.045)\end{array}$ & $\begin{array}{l}-0.013 \\
(0.049)\end{array}$ & $\begin{array}{l}-0.002 \\
(0.049)\end{array}$ & $\begin{array}{l}-0.013 \\
(0.048)\end{array}$ & $\begin{array}{c}-0.161 * * * \\
(0.058)\end{array}$ & $\begin{array}{c}-0.124 * * \\
(0.056)\end{array}$ & $\begin{array}{c}-0.131 * * \\
(0.051)\end{array}$ & $\begin{array}{c}-0.158 * * * \\
(0.059)\end{array}$ \\
\hline Square of In(capital) & $\begin{array}{c}0.000 \\
(0.001)\end{array}$ & $\begin{array}{c}0.001 \\
(0.001)\end{array}$ & $\begin{array}{c}0.000 \\
(0.001)\end{array}$ & $\begin{array}{c}0.000 \\
(0.001)\end{array}$ & $\begin{array}{c}0.000 \\
(0.001)\end{array}$ & $\begin{array}{c}0.004^{* * *} \\
(0.001)\end{array}$ & $\begin{array}{c}0.003 * * \\
(0.001)\end{array}$ & $\begin{array}{c}0.003^{* * *} \\
(0.001)\end{array}$ & $\begin{array}{c}0.004 * * * \\
(0.001)\end{array}$ \\
\hline In(value added per worker) & $\begin{array}{l}-0.016 \\
(0.019)\end{array}$ & $\begin{array}{l}-0.014 \\
(0.019)\end{array}$ & $\begin{array}{l}-0.019 \\
(0.020)\end{array}$ & $\begin{array}{l}-0.005 \\
(0.019)\end{array}$ & $\begin{array}{l}-0.011 \\
(0.020)\end{array}$ & $\begin{array}{c}-0.132 * * * \\
(0.047)\end{array}$ & $\begin{array}{l}-0.080 * \\
(0.047)\end{array}$ & $\begin{array}{c}-0.108^{* * *} \\
(0.040)\end{array}$ & $\begin{array}{c}-0.135^{* * *} \\
(0.048)\end{array}$ \\
\hline Square of In(value added per worker) & $\begin{array}{c}0.001 \\
(0.001)\end{array}$ & $\begin{array}{c}0.001 \\
(0.001)\end{array}$ & $\begin{array}{c}0.001 \\
(0.001)\end{array}$ & $\begin{array}{l}-0.000 \\
(0.001)\end{array}$ & $\begin{array}{c}0.000 \\
(0.001)\end{array}$ & $\begin{array}{l}0.004 * \\
(0.002)\end{array}$ & $\begin{array}{c}0.002 \\
(0.002)\end{array}$ & $\begin{array}{c}0.003 \\
(0.002)\end{array}$ & $\begin{array}{c}0.004^{* *} \\
(0.002)\end{array}$ \\
\hline Import/Value added & & $\begin{array}{l}-0.000 \\
(0.001)\end{array}$ & & & & & $\begin{array}{l}-0.033 \\
(0.024)\end{array}$ & & \\
\hline Export/Value added & & $\begin{array}{c}0.006 * * \\
(0.003)\end{array}$ & & & & & $\begin{array}{c}-0.057^{* *} \\
(0.023)\end{array}$ & & \\
\hline Tariff Turkey imposes & & & $\begin{array}{c}0.004 \\
(0.005)\end{array}$ & & & & & & \\
\hline Tariff Turkey faced & & & $\begin{array}{c}0.024 \\
(0.020)\end{array}$ & & & & & & \\
\hline Backward participation & & & & $\begin{array}{c}-0.034 * * * \\
(0.012)\end{array}$ & & & & $\begin{array}{c}-0.169 * * * \\
(0.046)\end{array}$ & \\
\hline Forward participation & & & & $\begin{array}{l}-0.002 \\
(0.003)\end{array}$ & & & & $\begin{array}{c}0.021 \\
(0.030)\end{array}$ & \\
\hline Inflow & & & & & $\begin{array}{c}0.006 \\
(0.005)\end{array}$ & & & & $\begin{array}{c}-0.007 * * \\
(0.003)\end{array}$ \\
\hline Outflow & & & & & $\begin{array}{c}0.007 \\
(0.005)\end{array}$ & & & & $\begin{array}{c}0.037 \\
(0.058)\end{array}$ \\
\hline \# of Observations & 120 & 120 & 120 & 120 & 120 & 110 & 110 & 110 & 110 \\
\hline
\end{tabular}

Notes: Robust standard errors in parentheses, $* * * p<0.01, * * p<0.05, * p<0.1$. Sector dummies are included in all specifications. The time dummies are significantly negative for the last three years of manufacturing sectors and the last six years of the service sectors. 
Table 5: Value added shares, 2005-2014

\begin{tabular}{|c|c|c|c|c|c|c|c|c|c|}
\hline \multirow{2}{*}{$\begin{array}{l}\text { Value added shares } \\
\text { VARIABLES }\end{array}$} & \multicolumn{5}{|c|}{ MANUFACTURING } & \multicolumn{4}{|c|}{ SERVICE } \\
\hline & (1) & $(2)$ & (3) & $(4)$ & (5) & (1) & $(2)$ & (3) & (4) \\
\hline In(capital) & $\begin{array}{l}-0.071 \\
(0.049)\end{array}$ & $\begin{array}{l}-0.003 \\
(0.042)\end{array}$ & $\begin{array}{l}-0.071 \\
(0.048)\end{array}$ & $\begin{array}{l}-0.057 \\
(0.042)\end{array}$ & $\begin{array}{l}-0.068 \\
(0.051)\end{array}$ & $\begin{array}{l}-0.035 \\
(0.029)\end{array}$ & $\begin{array}{l}-0.023 \\
(0.025)\end{array}$ & $\begin{array}{l}-0.026 \\
(0.027)\end{array}$ & $\begin{array}{l}-0.028 \\
(0.030)\end{array}$ \\
\hline Square of In(capital) & $\begin{array}{c}0.002 \\
(0.001)\end{array}$ & $\begin{array}{l}-0.000 \\
(0.001)\end{array}$ & $\begin{array}{c}0.002 \\
(0.001)\end{array}$ & $\begin{array}{c}0.001 \\
(0.001)\end{array}$ & $\begin{array}{c}0.001 \\
(0.001)\end{array}$ & $\begin{array}{c}0.001 \\
(0.001)\end{array}$ & $\begin{array}{c}0.001 \\
(0.001)\end{array}$ & $\begin{array}{c}0.001 \\
(0.001)\end{array}$ & $\begin{array}{c}0.001 \\
(0.001)\end{array}$ \\
\hline In(employment) & $\begin{array}{c}-0.073 * * * \\
(0.020)\end{array}$ & $\begin{array}{c}-0.038^{* *} \\
(0.017)\end{array}$ & $\begin{array}{c}-0.069 * * * \\
(0.019)\end{array}$ & $\begin{array}{c}-0.051^{* * *} \\
(0.017)\end{array}$ & $\begin{array}{c}-0.074 * * * \\
(0.020)\end{array}$ & $\begin{array}{l}0.025^{*} \\
(0.013)\end{array}$ & $\begin{array}{c}0.039 * * * \\
(0.013)\end{array}$ & $\begin{array}{c}0.013 \\
(0.011)\end{array}$ & $\begin{array}{l}0.023^{*} \\
(0.014)\end{array}$ \\
\hline Square of In(employment) & $\begin{array}{c}0.003 * * * \\
(0.001)\end{array}$ & $\begin{array}{l}0.002^{* *} \\
(0.001)\end{array}$ & $\begin{array}{c}0.003 * * * \\
(0.001)\end{array}$ & $\begin{array}{c}0.002 * * * \\
(0.001)\end{array}$ & $\begin{array}{c}0.003 * * * \\
(0.001)\end{array}$ & $\begin{array}{l}-0.001 \\
(0.001)\end{array}$ & $\begin{array}{c}-0.001 * * \\
(0.001)\end{array}$ & $\begin{array}{l}-0.000 \\
(0.000)\end{array}$ & $\begin{array}{l}-0.001 \\
(0.001)\end{array}$ \\
\hline Import/Value added & & $\begin{array}{c}-0.001 \\
(0.001)\end{array}$ & & & & & $\begin{array}{c}-0.003 \\
(0.014)\end{array}$ & & \\
\hline Export/Value added & & $\begin{array}{c}-0.011 * * * \\
(0.002)\end{array}$ & & & & & $\begin{array}{c}-0.048 * * * \\
(0.013)\end{array}$ & & \\
\hline Tariff Turkey imposes & & & $\begin{array}{c}-0.004 \\
(0.010)\end{array}$ & & & & & & \\
\hline Tariff Turkey faced & & & $\begin{array}{l}-0.005 \\
(0.015)\end{array}$ & & & & & & \\
\hline Backward participation & & & & $\begin{array}{c}-0.058^{* * *} \\
(0.007)\end{array}$ & & & & $\begin{array}{c}-0.106 * * * \\
(0.028)\end{array}$ & \\
\hline Forward participation & & & & $\begin{array}{l}-0.004^{*} \\
(0.002)\end{array}$ & & & & $\begin{array}{c}0.042 * * \\
(0.021)\end{array}$ & \\
\hline Inflow & & & & & $\begin{array}{c}-0.010 \\
(0.007)\end{array}$ & & & & $\begin{array}{c}-0.008 * * * \\
(0.002)\end{array}$ \\
\hline Outflow & & & & & $\begin{array}{c}0.002 \\
(0.004)\end{array}$ & & & & $\begin{array}{c}0.031 \\
(0.037)\end{array}$ \\
\hline \# of Observations & 120 & 120 & 120 & 120 & 120 & 110 & 110 & 110 & 110 \\
\hline
\end{tabular}

Notes: Robust standard errors in parentheses, ${ }^{* *} p<0.01,{ }^{* *} p<0.05,{ }^{*} p<0.1$. Sector dummies are included in all specifications. The time dummies are significantly positive in the second and the fourth specifications and they are positive but insignificant in the first, third, and fifth specifications for manufacturing sectors. Except for the first two years, the time dummies are all negative and significant in all specifications for service sectors. 


\section{Appendix}

Table A1: Industry Matching

\begin{tabular}{|c|c|c|c|c|c|c|c|c|c|}
\hline \multicolumn{5}{|c|}{ The $1^{\text {st }}$ Dataset ${ }^{7}$} & \multicolumn{5}{|c|}{ The $2^{\text {nd }}$ Dataset $^{8}$} \\
\hline Sector Definitions & WIOD 2014 & $\begin{array}{l}\text { TiVA } \\
2016\end{array}$ & WITS & CBRT & Sector Definitions & WIOD 2016 & \begin{tabular}{|l|} 
TiVA \\
2018 \\
\end{tabular} & WITS & CBRT \\
\hline $\begin{array}{l}\text { Food products, beverages and } \\
\text { tobacco }\end{array}$ & $15 \mathrm{t} 16$ & C15T16 & $15+16$ & TP.YD06 & $\begin{array}{l}\text { Food products, beverages } \\
\text { and tobacco }\end{array}$ & $\mathrm{C} 10-\mathrm{C} 12$ & D10T12 & $15+16$ & TP.YD06 \\
\hline $\begin{array}{l}\text { Textiles, textile products, leather } \\
\text { and footwear }\end{array}$ & $17 \mathrm{t} 18+19$ & C17T19 & $17+18+19$ & $\begin{array}{l}\text { TP.YD07 + } \\
\text { TP.YD08 }\end{array}$ & $\begin{array}{l}\text { Textiles, wearing apparel, } \\
\text { leather and related } \\
\text { products }\end{array}$ & $\mathrm{C} 13-\mathrm{C} 15$ & D13T15 & $\begin{array}{l}17+18+ \\
19\end{array}$ & $\begin{array}{l}\text { TP.YD07 + } \\
\text { TP.YD08 }\end{array}$ \\
\hline $\begin{array}{l}\text { Wood and products of wood and } \\
\text { cork }\end{array}$ & 20 & $\mathrm{C} 20$ & 20 & TP.YD09 & $\begin{array}{l}\text { Wood and products of } \\
\text { wood and cork }\end{array}$ & C16 & D16 & 20 & TP.YD09 \\
\hline $\begin{array}{l}\text { Coke, refined petroleum products } \\
\text { and nuclear fuel }\end{array}$ & 23 & $\mathrm{C} 23$ & 23 & TP.YD11 & $\begin{array}{l}\text { Coke and refined } \\
\text { petroleum products }\end{array}$ & C19 & D19 & 23 & TP.YD11 \\
\hline Chemicals and chemical products & 24 & $\mathrm{C} 24$ & 24 & TP.YD12 & $\begin{array}{l}\text { Chemicals and } \\
\text { pharmaceutical products }\end{array}$ & $\mathrm{C} 20+\mathrm{C} 21$ & D20T21 & 24 & TP.YD12 \\
\hline Rubber and plastics products & 25 & $\mathrm{C} 25$ & 25 & TP.YD13 & Rubber and plastic products & C22 & D22 & 25 & TP.YD13 \\
\hline Other non-metallic mineral products & 26 & $\mathrm{C} 26$ & 26 & TP.YD14 & $\begin{array}{l}\text { Other non-metallic mineral } \\
\text { products }\end{array}$ & $\mathrm{C} 23$ & D23 & 26 & TP.YD14 \\
\hline Machinery and equipment, nec & 29 & C29 & 25 & TP.YD16 & $\begin{array}{l}\text { Machinery and equipment, } \\
\text { nec }\end{array}$ & C28 & D28 & 29 & TP.YD16 \\
\hline
\end{tabular}

${ }^{7}$ For industry matching strategy, we use "industry breakdown for the 2016 TiVA Indicators" (WTO/OECD, 2016), "list of industries for TiVA 2018" (OECD, 2019a), "the notes for the differences between TiVA 2016 and TiVA 2018" (OECD, 2019a), "Eurostat SNA NACE Rev.2 (ISIC Rev.4) A*64 to A*10 hierarchy" (OECD, 2019b), "WIOD Socio-Economic Accounts (SEA): Sources and Methods" (Erumban et al., 2012), "Employment and Compensation in the WIOD Socio-Economic Accounts (SEA): Revisions for 2008/2009 and new data for 2010/2011" (Gouma et al., 2014), "Tariff and Trade Analysis Database" (WITS, 2019) and "International Investment Position Statistics" (CBRT, 2019).

${ }^{8}$ For industry matching strategy, we use "industry breakdown for the 2016 TiVA Indicators" (WTO/OECD, 2016), "list of industries for TiVA 2018" (OECD, 2019a), "the notes for the differences between TiVA 2016 and TiVA 2018" (OECD, 2019a), "Eurostat SNA NACE Rev.2 (ISIC Rev.4) A*64 to A*10 hierarchy" (OECD, 2019b), "WIOD Socio-Economic Accounts 2016: Sources and Methods" (Gouma et al., 2018), "Tariff and Trade Analysis Database" (WITS, 2019) and "International Investment Position Statistics" (CBRT, 2019). 
Table A1 (continued)

\begin{tabular}{|c|c|c|c|c|c|c|c|c|c|}
\hline \multicolumn{5}{|c|}{ The $1^{\text {st }}$ data set } & \multicolumn{5}{|c|}{ The $2^{\text {nd }}$ data set } \\
\hline Sector Definitions & WIOD 2014 & \begin{tabular}{|l|} 
TiVA \\
2016
\end{tabular} & WITS & CBRT & Sector Definitions & WIOD 2016 & \begin{tabular}{|l|} 
TiVA \\
2018 \\
\end{tabular} & WITS & CBRT \\
\hline Electricity, gas and water supply & E & C40T41 & $40+$ & $\begin{array}{l}\text { TP.YD20 + } \\
\text { TP.YD21 }\end{array}$ & $\begin{array}{l}\text { Electricity, gas, water } \\
\text { supply, sewerage, waste } \\
\text { and remediation services }\end{array}$ & $\begin{array}{l}\mathrm{D} 35+\mathrm{E} 36 \\
+\mathrm{E} 37-\mathrm{E} 39 \\
\end{array}$ & D35T39 & & $\begin{array}{l}\text { TP.YD20 + } \\
\text { TP.YD21 }\end{array}$ \\
\hline Wholesale and retail trade; repairs & $50+51+52$ & C50T52 & & TP.YD24 & $\begin{array}{l}\text { Wholesale and retail trade; } \\
\text { repair of motor vehicles }\end{array}$ & $\begin{array}{l}\mathrm{G} 45+\mathrm{G} 46+ \\
\mathrm{G} 47\end{array}$ & D45T47 & & TP.YD24 \\
\hline Transport and storage & $\begin{array}{l}60+61+62+ \\
63\end{array}$ & С60T63 & & TP.YD25 & Transportation and storage & $\begin{array}{l}\mathrm{H} 49+\mathrm{H} 50 \\
+\mathrm{H} 51+ \\
\mathrm{H} 52+\mathrm{H} 53 \\
\end{array}$ & D49T53 & & TP.YD25 \\
\hline Hotels and restaurants & $\mathrm{H}$ & C55 & & TP.YD26 & $\begin{array}{l}\text { Accommodation and food } \\
\text { services }\end{array}$ & 1 & D55T56 & & TP.YD26 \\
\hline Financial intermediation & $\mathrm{J}$ & C65T67 & & $\begin{array}{l}\text { TP.YD28 + } \\
\text { TP.YD29 + } \\
\text { TP.YD30 }\end{array}$ & $\begin{array}{l}\text { Financial and insurance } \\
\text { activities }\end{array}$ & $\begin{array}{l}\mathrm{K} 64+\mathrm{K} 65+ \\
\mathrm{K} 66\end{array}$ & D64T66 & & TP.YD28 \\
\hline Real estate activities & 70 & C70 & & TP.YD33 & Real estate activities & L68 & D68 & & TP.YD33 \\
\hline $\begin{array}{l}\text { Public admin. and defence; } \\
\text { compulsory social security }\end{array}$ & $\mathrm{L}$ & C75 & & TP.YD36 & $\begin{array}{l}\text { Public admin. and defence; } \\
\text { compulsory social security }\end{array}$ & 084 & D84 & & TP.YD36 \\
\hline Education & $\mathrm{M}$ & $\mathrm{C} 80$ & & TP.YD37 & Education & P85 & D85 & & TP.YD37 \\
\hline Health and social work & $\mathrm{N}$ & C85 & & TP.YD38 & $\begin{array}{l}\text { Human health and social } \\
\text { work }\end{array}$ & Q & D86T88 & & TP.YD38 \\
\hline $\begin{array}{l}\text { Private households with employed } \\
\text { persons }\end{array}$ & $\mathrm{P}$ & C95 & & TP.YD41 & $\begin{array}{l}\text { Private households with } \\
\text { employed persons }\end{array}$ & $T$ & D97T98 & & TP.YD41 \\
\hline Mining and quarrying & C & C10T14 & $\begin{array}{l}10+11+12+ \\
13+14\end{array}$ & TP.YD04 & Mining and quarrying & $\mathrm{B}$ & D05T09 & $\begin{array}{l}10+11+ \\
12+13+ \\
14\end{array}$ & TP.YD04 \\
\hline $\begin{array}{l}\text { Basic metals and fabricated metal } \\
\text { products }\end{array}$ & $27 \mathrm{t} 28$ & C27T28 & $27+28$ & TP.YD15 & $\begin{array}{l}\text { Basic metals and fabricated } \\
\text { metal products }\end{array}$ & $\mathrm{C} 24+\mathrm{C} 25$ & $\mathrm{D} 24 \mathrm{~T} 25$ & $27+28$ & TP.YD15 \\
\hline Electrical and optical equipment & $30 \mathrm{t} 33$ & С30Т33 & $\begin{array}{l}30+31+32+ \\
33\end{array}$ & TP.YD17 & $\begin{array}{l}\text { Computers, electronic and } \\
\text { electrical equipment }\end{array}$ & $\mathrm{C} 26+\mathrm{C} 27$ & D26T27 & $\begin{array}{l}30+31+ \\
32+33\end{array}$ & TP.YD17 \\
\hline Transport equipment & $34 \mathrm{t} 35$ & C34T35 & $34+35$ & TP.YD18 & Transport equipment & $\mathrm{C} 29+\mathrm{C} 30$ & D29T30 & $34+35$ & TP.YD18 \\
\hline
\end{tabular}

